Rozprawy Komisji Językowej ŁTN, t. LXVI, 2018

ISSN 0076-0390; e-ISSN 2450-9310

https://doi.org/10.26485/RKJ/2018/66/5

Thomas Daiber*

\title{
PAVLO ŽYTEC'KYJ AND ALEKSEJ A. ŠACHMATOV ON LANGUAGE IDEOLOGY AND THE STATUS OF THE UKRAINIAN LANGUAGE ${ }^{1}$
}

\author{
PAWŁO ŻYTEC'KYJ I ALEKSIEJ A. SZACHMATOW W SPRAWIE \\ POLITYKI JĘZYKOWEJ I STATUSU JĘZYKA UKRAIŃSKIEGO
}

This paper analyzes arguments about the status of the Ukrainian language in letters from P.I. Zhiteckij and A.A. Shachmatov, and shows that a shared language ideology may nevertheless lead to different political consequences.

Keywords: Pavlo I. Zhiteckij, Aleksej A. Shachmatov, Ukrainian Bible, Ukrainian language, language discourse of the $19^{\text {th }}$ century.

Słowa kluczowe: Pawło I. Żytec’kyj, Aleksiej A. Szachmatow, ukraińska Biblia, język ukraiński, dyskurs językowy w XIX w.

Pavlo Hnatovyč Žytec'kyj (Pavel Ignatovič Žiteckij, 1837-1911), one of the prominent actors in the beginning of Ukrainian philology, served most of his life as a teacher of Russian language in secondary schools in Kiev, with the exception of the years 1880-1882, when he gave lectures at the university of St. Petersburg on Slavic and Ukrainian historical linguistics. In Kiev, he never was accepted at university as lecturer or professor, surely because of his mem-

* Institut für Slavistik, Justus Liebig Universität, Otto-Behaghel-Straße 10D, 35394 Gießen, e-mail: thomas.daiber@slavistik.uni-giessen.de.

1 The article was written within the project "Die Ukraine: Überlappungsregion und Normexport in der Kulturwissenschaft" as part of the research cluster "Konfliktregionen im östlichen Europa" at Giessen university, funded by The Hessen State Ministry for Higher Education, Research and the Arts (LOEWE 2017-2020). I am very grateful to both anonymous reviewers of this article, whose remarks helped me to clarify some points. 
bership of "Hromada", a gathering of intellectuals for the national revival of the Ukraine. Later, as a sign of recognition for his work in the field of Slavic and Ukrainian philology, Žytec'kyj became a corresponding member of the Academy of Sciences in St. Petersburg in 1898, and finally, in 1908, was awarded a Doctor honoris causa at Kiev university².

Žytec'kyj is deemed to be the first historian of the Ukrainian language. In the same year 1876 appeared both his Очерк звуковой истории малоруського наречия and a book on the language of the Peresopnyc'ke Jevanhelije, which he later partially edited [Žiteckij, 1878]. Considered one of the most qualified scholars in the field of Ukrainian linguistics, Žytec'kyj was asked by the Petersburg Academy of Sciences if he would agree to write a history of Bible translations into the Ukrainian language. On Oct 6 1903, Aleksej Aleksandrovič Šachmatov (1864-1920), the youngest ever member of the Imperial Academy of Sciences, wrote to Žytec'kyj:

Вероятно, до Вас уже дошла посылка с рукописями Морачевского и Лободовского и просьба Академии. Мы очень надеемся, что Вы не откажетесь ее исполнить. Весьма было бы желательно, чтобы филологическому исследованию переводов Вы предпочли историческую записку о попытках передать Слово Божие по-малорусски. Вам составить такую записку легче, чем кому-нибудь иному [ed. Makarov, 2012, see also there note no. 17].

Surely, the package with the manuscripts of Moračevskij and Lobodovskij already came to you together with the request of the Academy. We trust very much in you, that you won't refuse to fulfil it. It would be extremely desirable, if you would prefer to a philological investigation, a historical record of the attempts to reproduce God's Word in the Little Russian language. To compile such a record will be easier for you, than for anybody else. ${ }^{3}$

The Academy - in the person of Šachmatov - asked Žytec'kyj to put back any planned philological research on Ukrainian Bible translations, to instead compile a historical record of all Ukrainian Bible translations existing so far. In his following letters Šachmatov repeatedly asked for the historical overview, while Žytec'kyj declared himself to be unable to deliver such a work because he would not be able to collect all the necessary material in so short a time and also because of poor health and painful family circumstances. While Šachmatov kept asking for a historical overview, Žytec'kyj finally delivered a philological investigation instead [Žiteckij, 1905].

2 Short biography and review of Žytec'kyj's linguistic work in Beloded [1968], see also Senkus [1993].

3 All translations in this article Th.D.; terminological consistency between the translations has been kept at the cost of more stylistically appropriate formulations. 
This paper does not intend to speak about the translational or linguistic peculiarities of Ukrainian Bible translations [see literature in Danylenko, 2016 and Remy, 2016], nor about the role of Ukrainian in religious contexts [Moser, 2005] nor about the history of Moračevs'kyj's translation in particular [see also Esipova, 2014]. The paper touches those topics only for laying out the historical context within which the letters of Šachmatov and Žytec'kyj can be understood. We are interested in the question, how Šachmatov and Žytec'kyj both shared the language ideology of their time (and maybe not only of their time), but differed significantly in their political conclusions concerning the status of the Ukrainian language.

\section{STEMS AND BRANCHES}

The Academy's request for a historical record and not a philological work was backgrounded by preparations to finally see in print the Ukrainian translation of the New Testament made by Pilip Semenovič Moračevs'kyj (1806-1879). However, the history of reviewing Moračevs'kyj's Bible translation reaches back much further. As early as in the year 1865 Moračevs'kyj himself had sent his translation to the Academy, which is known from a letter of the Academy of May 20, 1865, acknowledging the receipt of the manuscript [Kotenko, 2014, p. 102]. Sending his manuscript to the Academy of Sciences was Moračevs'kyj's second (possibly third ${ }^{4}$ ) attempt to receive permission for printing his translation. 5 years before, in 1860, he had already sent the translation of the first two Gospels to Metropolitan bishop Isidor (Jakov Sergeevič Nikol'skij, in office as bishop of Petersburg and Novgorod since July 1860), who vaguely answered, that the Ukrainian translation could not be admitted to print. Seemingly, Isidor did not present Moračevs'kyj's translation for official consideration by the Holy Synod and just sent it back to the translator [Vulpius, 2005, p. 195 et seq.].

In submitting his translation to the Petersburg Academy of Sciences in the year 1865, Moračevs'kyj had been more successful. The manuscript was judged by the Academy as a brilliant work and subsequently transferred to the Holy Synod. Probably at this point in the chain of events, being officially delivered for review to the Holy Synod, Moračevs'kyj's translation received the attention also of Russian political administrative officers who were not interested in its

4 V.A. Hluščenko [2014] reports, that already in 1861 Moračevs'kyj had sent his translation (most probably only the first two Gospels) to the Academy and Izmail Ivanovič Sreznevskij considered the manuscript a "good work". Thus, Moračevs'kyj had discovered, that his translation would best find its way to official consideration by the Holy Synod if it were submitted there by the Academy. 
printed publication. Moračevs'kyj finally died in 1879 , never seeing any results of his efforts.

When Šachmatov writes to Žytec'kyj in 1903, that the Academy would be interested in a historical overview about Ukrainian Bible translations, his request is still connected with Moračevs'kyj's translation. In the year 1900, a grandson of Moračevs'kyj had donated a manuscript of the completed translation of his grandfather to the Academy of Sciences, which came to the notion of Šachmatov who was then very engaged in the Ukrainian matter. The political climate seemed to be in favour of a new effort towards a printed Ukrainian Bible translation. In the course of the Russo-Japanese war, Tsar Nicholas II, in order to keep up the solidarity of citizens and subordinates, had issued a decree on Dec 12, 1904, that all "superfluous" restrictions in censoring "the printed word" should be discontinued [Basargina, 2004, p. 209]. This is the reason, why Šachmatov in a letter to Žytec'kyj from Febr 25, 1905, is optimistic enough to believe that the "laws" (закон) of 1876 and 1881, which prohibited public use of the Ukrainian language, soon would be revoked. The Ems decree of Tsar Aleksandr II of May 30, 1876, a successor to the Valuev Circular of 1863 banned the use of the Ukrainian language in print [Remy, 2007; Danylenko, 2010]. After the assassination of Alexander II (March 1, 1881), his son Alexander III granted by decree from Aug 14, 1881 (gradually prolonged until 1917) exclusive rights to the executive forces [Bijuškina, 2010] in order to prevent any political opposition. Alexander's decree, "codifying and systematizing the repressive legislation dating back at least to 1845 " [Cracraft, 1982, p. 10] put Russia in a virtual state of exception [cf. Frank, 1999, pp. 64-65, see Domrin, 20105] and discouraged private or non-official initiatives in favour of the Ukrainian language. Nevertheless, in January 1881 a proposal by the governor-generals of Kyjiv and Char'kiv resulted in the directive and later law from Oct $8(20), 1881$, which approved on the one hand the restrictions of 1876, but allowed the printing of Ukrainian dictionaries and "lyrical compositions" - however in Russian orthography [cf. Solchanyk, 1985, p. 61]. In his letter to Žytec'kyj of February 1905 Šachmatov alludes to the Ems Decree and the law from 1881, as does the Academy of Sciences in that same year 1905, when issuing a memorandum, authored by, in fact, only two (Šachmatov and Korš, see below) of its members, concerning the "Withdrawal of the limitations for the printed Ukrainian word" (Об отмене стеснений малорусского

5 Domrin [2010, p. 67]: "In reality, neither the fact of issuance of the Emergency Law in Russia, nor its substance, nor its use, was unique. Adoption of special statutes regulating the legal regime of a state of emergency was a common trend of European lawmaking (Prussia, AustriaHungary, Spain, etc.) in the middle and second half of the nineteenth century". 
печатного слова). The memorandum alludes in its title ("printed word") to the decree of Nicholas II and quotes in its first pages the Ems decree from 1876 and the directive from 1881. The statement of the Academy argues, that, of course, every measure should be taken to guarantee the unity of the Russian empire, but in the case of the Ukraine it would be obvious that the free use of the Ukrainian language has not been and never will be accompanied by separatist movements:

Императорская Академия Наук [...] не может не признать, что цензурные стеснения малорусского печатного слова [...] не были вызваны какими бы то ни было угрожающими единству России стремлениями малорусского народа или его интеллигенции. Равным образом, ничто не указывает на существование таких стремлений и теперь [Ob otmene stesnenij malorusskogo pečatnogo slova..., 1905, II].

The Imperial Academy of Sciences cannot but perceive, that censorship obstructions of the Little Russian printed word [...] were not stimulated by any movements whatsoever of the Little Russian people or their intellectual elite which could be a threat to the unity of Russia. Equally, nothing points to the existence of such movements also at the present time.

Академия Наук не может не заметит, что русское законодатлеьство [...] держалось всегда того правила, что печатное слово может быть предметом преследования [...] только за внутренний смысл того, что́ им выражено [...]. Только сцепление несчастных случайностей могло поэтому подвести под запрет целый язык [Ob otmene stesnenij malorusskogo pečatnogo slova..., 1905, p. II].

The Imperial Academy of Sciences cannot but realize, that the Russian legislature [...] always kept as a rule, that a printed word can become an object of persecution [...] only in regard to the embedded meaning of that, what is expressed by it [...]. Only a concatenation of unfortunate circumstances therefore could put a language as a whole under prohibition.

Но в действительности малорусская литература до половины 40-х годов отличалась от великорусской именно только своим глубоким, последовательным демократизмом, что вполне понятно, так как малорусская народность была тогда представляема почти только низшими сословиями. [...] сущност [Кирилло-тефодиевского братства, Th.D. ${ }^{6}$ ] было просто литературное и народно-воспитательное движение южной ветви Русского народа [Ob otmene stesnenij malorusskogo pečatnogo slova ..., 1905, 4pp].

But indeed the Little Russian literature up to the middle of the 40s differed from the Great Russian literature particularly only in its deep, successive democratism, which is fully understandable, because the nationality of the Little Russian people nearly exclusively was represented by its lowest estates. [...] The existence [of the Brotherhood of Saints Cyril and Methodius, Th.D.] has only been a literary and public educational movement (literally: educational movement of the people) of the southern branch of the Russian people.

6 The "Brotherhood" was a not very coherent union of nationalist-inspired and mainly literarlly engaged Ukrainian intellectuals [Glassl, 1985]. V.J. Aristov [2010, p. 22] points out, that until the second half of the $19^{\text {th }}$ century the 'Ukrainophiles' had no problem to combine a Ukrainian identity with loyalty to the Russian state. But see also the turning away from "traditional" Ukrainophilia in the 1890s [Michutina, 2003, p. 63 et seq.]. 
Remarkably enough, the memorandum notes the ban of a "whole language" (язык) while in other passages of the text also the term "vernacular" (наречие) occurs in reference to Ukrainian. The terminological ambiguity may not only be motivated by rhetorical considerations, but reflects the strategy of the whole statement. The memorandum tries to demonstrate that the Ukrainian language developed out of an old and rich literary tradition and displays a long-standing and non-negotiable existence, and additionally argues, that all so-called "democratic" associations connected with the use of the Ukrainian language - the only difference to the Great Russian literature - should not be seen as expressions of separatism from Russia, but on the contrary consist in fact in much needed educational work for the benefit of Ukraine's inhabitants who, with the help of education in their own language, could much better contribute to the general welfare of the Russian empire. Ukrainian people are, according to the memorandum, the "southern branch of the Russian people", the "little" brother of the "greater" Russian one [cf. Remy, 2016, 19pp. about associations connected with the term "Little Russia"] and would not desire a political split between Russia and the Ukraine. Both, Šachmatov's letter to Žytec'kyj requesting an historical overview of Ukrainian Bible translations and the public initiative of the Petersburg Academy to finally see a first Ukrainian Bible in print, were undertaken in a period when a more relaxed political stance towards the Ukrainian language seemed possible.

\section{BROTHER-MOTHER}

After having contextualised the letters of Šachmatov to Žytec'kyj we shall now take a closer look at discourse patterns. Related to the Academy's memorandum the question arises, to what extend the acknowledgement of the existence of a separate language inevitably entails - according to common linguistic thinking in the $19^{\text {th }}$ century - the acknowledgment of the existence of a separate nation and thus inevitably involves the question of national sovereignty.

In order to answer this question a short reference is needed, however sketchy, to philosophical arguments on language and nation building in the $19^{\text {th }}$ century. The analyse of the political use of language arguments and the specific intentions connected with them when propagated by certain actors is left to the historic sciences. Various documents [e.g. Borjak, 2013] show, that the request for a "literary language" must not inevitably be connected with the intention of nation building, but, of course, the administration of the Russian empire considered the request for а литературный язык always as a first step towards national separation, especially in the Ukraine, where the Habsburg policy in Galicia did not 
contribute to a more relaxed stance on language questions. In order to understand the terms and concepts used in the memorandum of the Academy and writings of Šachmatov and Žytec'kyj an abstract overview of the discourse patterns is needed, as they occur in debates about language and nation.

The discourse patterns on language and nation in the $19^{\text {th }} \mathrm{c}$., as they appear systematized in Schelling's lectures about Mythology [1842, published in Schelling, 1985, vol. 5; cf. Daiber, 2008], can be drawn together as follows: A "nation" starts as a "tribe" (Stamm, племя), organized by family bonds with a certain "way of speaking" (Mundart, говор). Giving the tribe an organization on a level superior to family bonds (e.g. feudalism) makes it a "people" (Volk, народ) with a certain "dialect" (Volkssprache, vernacular, наречие). The "dialect" is still considered to exist more or less only orally, but the political and intellectual elites may use it as a uniform medium of communication. When the "people" make one step further in creating a self-organization, based not only on the sway of individual actors, but on the spiritual, ideological incorporation of every member into an "imagined community" [Anderson, 1991], the once raw "people" will turn into a refined "nation" now using a uniformly normalized "language" (Sprache, язык) in written form which, as it should be according to theory, can serve to express every nuance from the most emotional sentiment of the simpler members of the community (typically peasants, producing at the most 'lyrical compositions'; see above) up to the most sophisticated, philosophical creations of the nation's most gifted member (the nation's geniuses $=$ writers, composers, philosophers). The national language is said to express the national character (Nationalcharakter, nationality, народность) of the collective and language in its "highest" use always appears as the "literary language", as the written" spiritual refinement of a once oral animal instinct.

It is crucial to note, that the philosophical theory of collective organisations and their corresponding linguistic varieties lacks one fundamental explanation. It does not explain historical change. Why do some "people with dialects" manage to become "nations with languages" while others drop out of history or stay forever (e.g. Ukrainians in $19^{\text {th }} \mathrm{c}$. Russian judgment) on the level "people with

7 The law of 1881 (see above) demanded, that Ukrainian should only be printed with the Russian stock of cyrillic letters. The instruction demonstrates the meaning of "literacy" in the discourse: Ukrainian was not allowed to be displayed as a "language" which incorporates itself in letters (like the nation's genius incorporates itself in language). Medial and normative differences between "dialect" and "language", here omitted for the sake of brevity, are reflected in grammar production, which also displays the scheme "people with dialect/vernacular" and "nation with literary language" [cf. Daiber, 2014]. 
dialect"? Schelling speaks of a "hidden power" ("verborgene Macht" [Daiber, 2008 , p. 79]) which regulates the uprising of nations and the dying out of tribes. In other words, the philosophical system is arguing post factum: an existing "nation with language" has proven to have the inherent vital power to be a nation. History vindicates itself. We will see that in the memorandum of the Academy the "historical role" of Russia has the last word.

Within the continuum говор - наречие - язык the Ukrainian language had always been classified as a minor "dialect" (малорусское наречие) of the great Russian "language" (русский язык), as is clear from the comments in Aleksej Pavlovič Pavlovskij's $(1978=1818)$ first grammar of Ukrainian [Daiber, 2008 ${ }^{8}$ ]. Pavlovskij had written his grammar in 1818 at a time, when historical linguistics had just started to become the dominant theory for the study of language, and the memorandum of the Academy of 1905 is written at a time, when linguists like Žytec'kyj and Šachmatov were perfectly informed that language development follows certain paths of grammaticalization, regular sound change being the most prominent research domain of Slavic historical linguistics at that time. But, unrelated to their professional insights both linguists use the key words of the political discourse to formulate idealistic concepts.

Šachmatov writes in a letter to Fedor Evgen'evič Korš from Febr 23, 1905, that the following passage out of an article by Russian Slavophile writer Jurij Fedorovič Samarin ${ }^{9}$ should be included in the memorandum:

Пусть же украинский народ сохраняет свой язык, свои обычаи, свои песни, свои предания пусть в братском общении и рука об руку с великим русским племенем развивает он на поприще науки и искусства, для которых так щедро наделила его природа, свою духовную самобытность всей природной оригинальности ее стремлений... Но в тоже время пусть он помнит, что историческая роль его - в пределах России, а не вне ее, в общем составе государства Московского, для создания и возвеличения которого так долго и упорно трудилось великорусское племя, для которого принесено им было так много кровавых жертв и перенесено страдании. [Makarov, 2015, p. 19]

8 See more quotes on the Ukrainian language in Aleksandrovskij [2009], however without reference to dominating discourse patterns.

9 Also quoted in [Simonova, 1988, p. 49], from where I took the bibliographical information; the quotation is from the last passage of Samarin's [1877] article "From the diary, written by Ju. F. Samarin in Kiev 1850" (Makarov has возвышения "elevation" instead of возвеличения "enlargement" and страдании instead of GenPl, omitting the last two words of the sentence). The passage ends with the words [... страданий], неведомых Украинцам; пусть помнит, что это государство спасло и его самостоятельность; пусть, одним словом, хранит, не искажая его, завет своей истории и изучает нашу. = "[... sufferings], unknown to the Ukrainians; may they remember, that this [Russian] state saved also their autonomy; may they, in one word, preserve, by not perverting it, the legacy of their history and study ours". 
May the Ukrainian people preserve their language, their customs, their songs, their traditions [,] may they develop in fraternal communication and hand in hand together with the Great Russian tribe their spiritual identity by all natural originality of their intentions in the field of science and arts, with those their nature so lavishly has endowed them... But may they be aware at the same time, that their historical role lies within the boundaries of Russia, not outside of her, in the common structure of the Muscovite state, for its creation and enlargement the Great Russian tribe has worked so long and so hard and has offered so many bloody sacrifices and endured sufferings.

According to the discourse about nation and language in the $19^{\text {th }} \mathrm{c}$. the quoted statement seems terminologically incongruent; the existence of a Ukrainian language (язык) is admitted, but the corresponding term for the collective of speakers is "people" (народ). Judging from the viewpoint of Schelling's system, "language" should not be connected with "people" but with "nation". But the terminological equations "dialect - people" and "language - nation", which are displayed in Schelling's German writings, are not easily traced in other languages. The Russian word народ changes (in singular) between "people" and "nation" and so does - by the way - the adjective "russkij" itself, which starting from the $16^{\text {th }}$ century [Trubačev, 2005, p. $230^{10}$ ] in Tsarist documents and eventually was doubled by the adjective "rossijskij", the latter denoting not so much an ethnic (people) but a governmental unit (nation). T. Kamusella [2012, pp. 95-96] hypothesizes, that "russkij" came to dominate "rossijskij" in the 1830s in the course of Russian adoption of the former Polish-Lithuanian lands. That may well be, however neither the ambiguous meaning of the Russian word народ (people or nation?) nor the use of the term русский in the quotation from Šachmatov/ Samarin provides a base for further terminological argument. Instead, the argu-

${ }^{10}$ Not very convincingly Trubačev [2005] does not touch any Russian ideology possibly connected with "rossijskij", but declares the word to be "artificial" (230 and passim), related to Russia's integration into Europe (234f.) and bearing threads of Russia's disintegration. As said above, an empire's first fear is disintegration into nations. Nota bene, this not only concerns the Russian empire, but also the European Union, which can be described as an empire, too [Del Sarto, 2016, p. 216: "Moreover, empires have typically engaged in some sort of 'civilizing mission', linked to a normative perception of themselves."]. But is "rossijskij" in fact an artificial term if it is regularly in use since the beginning of the $18^{\text {th }} \mathrm{c}$.? "The state was dubbed Rossiia, its population, Rossiiane, and the language, Rossiiskii. This consensus began to unravel in the 1830s and 1840s, and was definitively broken by the 1850 s. It was replaced with Russkii for the empire's population and its language, while the polity's name remained the same as before, Rossiia" [Kamusella, 2012, p. 88, without reference to Trubačev, 2005]. Symaniec [2013, p. 225] is very clear about the ideological background of the distinction between "russkij/rossijskij", which served as a means of ethnic differentiation between Russians, Belorussians and Ukrainians and at the same time gave reason to unify all different groups within an imperial state. 
mentative incongruence of the quoted passage is visible in its use of the term "tribe" (племя) which serves as the base for the concept of the relations between Russia and Ukraine.

The text appeals to a common "tribe" (племя) to legitimate an indivisible connection between Russia and Ukraine. But the "tribe" is twice called "Great Russian" and not - as it should be logically - a common ancestor to both Ukraine and Russia. In the first step, Russia and Ukraine are conceptualized as siblings, individuals by nature. Note nature's "lyric gift" to rural Ukraine, a classic stereotype for lovely, but slightly less civilized people, which seems like a quotation from the introductory words of Pavlovskij's grammar. While the siblings are growing up together hand in hand, Russia, however, is not only brother or sister, but at the same time the "tribe", the originating ground of Ukraine, too. It is history which legitimates the Russian sibling to be at the same time the origin of the Ukraine, and Ukraine's historical role can only be defined within the reach of "mother" Russia.

The memorandum of the Petersburg academy uses terms from the discourse about nation and language, but declares for historical reasons that there can only be one Muscovite nation. Such vindication post factum, as noted above, is part of the discourse. In comparison let us quote a passage from an early article, which Žytec'kyj wrote as a student in 1862:

Если правда, что Малорусский народ в самом строе своей духовной природы похож более на самого себя, чем на кого-нибудь, - что неотразимо доказал Шевченко своей поэзией и Костомаров - историей (в статье «Две русские народности»), то что мешает ему понимать и воспроизводить идеалы, присущие всему Русскому племени, по-своему, и рядом с Великорусской народностью идти к одной цели, только своей дорогой? [ed. in Sinica, 2014, p. 16]

If it is true, that the Little Russian people in the structure of their mental nature resemble mostly themselves and not someone else - as Ševčenko irresistibly demonstrated in his poetry and Kostomarov in his historical writings (in the article "Two Russian nationalities"), then what hinders them from realizing and reproducing the ideals, which are common to the whole Russian tribe, in their own way, and to go together with the Great Russian nationality towards one goal, only on their own path?

Also Žytec'kyj uses the terms "people" (народ) with its nature-given characteristics, however, the common ancestor of Ukraine and Russia is not called - contrary to the Academy's memorandum - the "Great Russian tribe", but only the "Russian" tribe, and so the concept of two siblings with a common ancestor is coherent. The unclear point in the argumentation of Žytec'kyj also relates to history: How is it possible, to go side by side to the same goal, but on different 
paths? If you go on a different path, then you are not side by side to the other. "Side by side" (рядом) can only be understood as a metaphor, somehow in the sense of a spiritual brotherhood with a common spiritual goal.

\section{A PHILOLOGICAL INVESTIGATION}

Šachmatov's and Žytec'kyj's correspondence, if framed by historical and conceptual conditions of the $19^{\text {th }} \mathrm{c}$., entails two different intentions connected with the request of the Academy, that Žytec'kyj may deliver an overview about Ukrainian Bible translations: The Academy or, to be exact, Šachmatov, who is practically the only one concerned with the Ukrainian issue, is interested in a history of Ukrainian Bible translations as documentation of an ancient branch to the Russian origin; Žytec'kyj, on the contrary, is interested in philological research about Ukrainian Bible translations as a documentation, that the Ukrainian language is a linguistically autonomous offspring of an origin common to both Russians and Ukrainians.

Finally, in the year 1905, Žytec'kyj delivered a paper about Ukrainian Bible translations to St.-Petersburg, which was subsequently printed in the Academy's journal. What he first called an "overview" (обозрение) in a letter to Šachmatov from 3 Sept, 1903, was later (Oct 14, 1904) announced "not as a single article, but a series of articles", of which none had been begun at the moment of his writing (это не будет статья, а целый ряд статей, из которых ни одна еще не начата). In the end, Žytec'kyj submitted one article, which in printed form comprises 65 pages; the first 42 pages are concerned with linguistic peculiarities of the Ukrainian language and the Bible translations, while an additional part displays specimen translations from the New Testament. The article starts with a political term:

Можно видеть некоторые следы славянофильства в известных словах начальной летописи: «а Словенеск язык и Русскый один», ${ }^{11}$ с тем различием от позднейшего

${ }^{11}$ At Žytec'kyj's time the debate about the relation between Church Slavonic and the East Slavonic vernaculars was not seen from a sociolinguistic point of view, which is the base for the - also politically inspired - discussion, who and when used Church Slavonic in contrast to the vernacular (to just name extreme positions: Did the "feudal" classes use Church Slavonic in contrast to the working people who only spoke the vernacular? Orwas there a "diglossia" which every speaker of the Rus' was aware of?; see Kretschmer [1994] as a first approach to a still to be written history about linguistic debates in the 70s and $80 \mathrm{~s}$ ). According to the non-sociological approach of his time, Žytec'kyj understands the alternation 'Slavonic or Russian language' not so much in the sense of a ('bilingual' or 'diglottic') coexistence of two lingual varieties, but rather as terms for origin (Slavonic) and offspring (Russian), and is arguing, that not only Russian but 
славянофильства, что центр тАжести для летописца и образованных современников его был не в русском языке, а в славянском. Знали они о разных племенах славянских [...] Таково было книжное предание в киевской руси, по которому не славянские ручьи сливались в русском море, а наоборот - русские в славянском.

It is possible to see some traces of slavophilia in the well-known words of the first chronicle: "however, the Slavonic tongue and the Russian are one and the same", albeit different from later slavophilia that for the chronicler and his educated contemporaries the centre of gravity had not been in the Russian, but in the Slavic language. They were informed about different Slavic tribes [...] Such has been the literary tradition in the Kievan Rus', according to which not the Slavic creeks join the Russian ocean but on the contrary, the Russian creek joins the Slavic ocean.

Žytec'kyj opened his linguistic considerations about the Ukrainian Bible language with the word "slavophilia", a concept to which the Tsarist police could react nervously. As it is well known, the Congresses of Slavs, organized since 1848 in various regions of Europe, were burdened from the very beginning with the problem that the Polish delegation argued not only for autonomy from the Habsburg and Prussian occupation, but also from the Russian one. And the Russian delegation could never come to terms with the demands of other Slavic nations in favour of building up nation states, because national ideas seemed to pose a separatist threat to imperial claims. On the one hand, using the term "slavophilia" is a politically clear statement from the side of Žytec'kyj, and it has to be acknowledged that the Academy submitted it to print. On the other hand, the term "slavophilia" must not be inevitably connected with separatist ideas, as Šachmatov's use of Samarin's words demonstrate (see above), the latter being a clear opponent to any Ukrainian separatism. While it is undecided whether separatism is included in the meaning of "slavophilia", the following words of Žytec'ky express clearly, that the existence of a Ukrainian language in its own right implies that its position towards Russian is not the position of an offspring to Russian, but of a sibling with equal rights, and Russian is one amongst other distinct continuations of the origin, not the origin itself.

The linguistic arguments of Žytec'kyj 1905 support his view, that Ukrainian is a Slavic sibling with equal rights compared to Russian. An actual linguistic review of Žytec'kyj's arguments would have to understand them within the framework of Slavic linguistics of his time, which basically would be an investigation into

Ukrainian as well could be an offspring of the common source. This is illustrated by the fact, that Žytec'kyj identifies without hesitation the term словенск язык (Slavonic language, in Žytec'kyjs orthography) and славянский (Slavic language, Slavic tribes), as if Church Slavonic would be the origin of all Slavic languages. Because of this conception, Žytec'kyj connects the sentence of the Chronicle with "slavophilia". 
the history of Slavic linguistics itself. Notwithstanding the linguistic validity of Žytec'kyj 1905, the method applied in his article shows that the philological analysis of Ukrainian Bible translations serves as a demonstration of the antiquity of the Ukrainian language, which, like Russian and independent of its influence, would equally touch upon the oldest fundament of the Slavic languages. On phonological and, remarkably enough, syntactical material Žytec'kyj 1905 demonstrates how Ukrainian preserves traces of the "old" Slavonic language, which is not coined Proto Slavic, Common Slavic, Common East Slavic or the like, but simply is associated with the language of the oldest Church Slavonic manuscripts of Bulgarian, casually also of Serbian redaction. Žytec'kyj does not follow the (stereotypical) line of argumentation, that a certain language - in his case Ukrainian - would have best preserved, quantitatively and qualitatively, traces of the historical origin, but argues instead, that Ukrainian like Russian or other Slavic languages, gave up to some extent "old" synthetic constructions and developed analytical means for syntactic cohesion:

Но если и теперь еще в малорусском наречии продолжается старинная традиция в построении речи, то из этого вовсе не следует, что она составляет в ней господствующее начало. Малорусское наречие в своем историческом развитии шло тем же путем, как и все другие, т.е. теряя старинную сжатость предложения и безразличие его составных частей, постепенно переходило к аналитическому строю речи [Žiteckij, 1905, p. 10]. But if until now the Little Russian dialect still continues the old tradition in the construction of the speech, in no way does it follow from that, that the old tradition would form the dominating principle in it. The Little Russian dialect went in its historical development on the same path, like all other [Slavic dialects], this is, losing the old conciseness of the sentence and the indifference of its constitutive components, it gradually went over to an analytical formation of the speech.

In a second step Žytec'kyj shows, that the language of the Peresopnyc'ke jevanhelije and of the liturgical language in Ukraine is influenced by middle Bulgarian Church Slavonic [Žiteckij, 1905, p. 13] in contrast to the language of the (Russian Church Slavonic) Gospel of Ostromir. By mentioning Smotryc'kyj's grammar of 1619 [p. 15], which would have treated a partially unknown to him "fictive language", Žytec'kyj justifiably claims that the beginnings of Church Slavonic grammar writing in the Ukraine became normative for Church Slavonic writings in Russia, too. ${ }^{12}$ Žytec'kyj is well informed about Smotryc'kyj's some-

${ }^{12}$ Another sensitive political point in Russian-Ukrainian relations is religious confession. Smotryc'kyj's grammar appeared in Jev'e, but was reprinted in Moscow as an anonymous work, after the author had converted to the Unitarian Church [Horbatsch, 1964; Daiber, 1992, p. 85]. I do not think that Žytec'kyj was aware of this fact; while the seminal work about old Slavic grammatography had already appeared [Jagić, 1895], it was not particularly concerned with Smotryc'kyj and the reception of his Grammar. 
times artificial morphological paradigms in his grammar, and he attests the Ukrainian writers of the $17^{\text {th }}$ century that they wrote Smotryc'kyj's Church Slavonic in Russian redaction, but their language would have influenced also Russian writers [e.g. Lomonosov; Žiteckij, 1905, p. 18]. In the $18^{\text {th }}$ century, Ukrainian writers already would not have had a full command of Church Slavonic according to Smotryc'ky's norms, and therefore would have made a sort of mixture of Church Slavonic with the Ukrainian vernacular [славяномалорусский язык, "Slavonic Little Russian language"; Žiteckij, 1905, p. 20], before embracing the Ukrainian vernacular as their literary language [p. 21]. As a summary, in accordance with the particular purpose of his article Žytec'kyj comes to the conclusion, that Ukrainian, in respect of the language of the Ukrainian Bible translations, has to be considered a cultivated language, based on the vernacular of the people, but showing more refined expressions in the realm of semantics and syntax. In other words - if we remember the language arguments of the $19^{\text {th }}$ century - Ukrainian as a "cultural" [культурный язык, p. 21] educated language bears all the marks of a national language: in contrast to the language of the people, which is apt to express "sorrow and laughter" [выражения печалей и радостей, p. 20], Ukrainian would have reached the status of a literary language in Kotljarevs'kyj's Ėneida, which widened the "horizon" of the Ukrainian language from a "local literature" to "global" themes. Žytec'kyj is arguing right along the lines of language philosophy of the $19^{\text {th }}$ century and the last passage from his summary frankly exposes the political undertone which is associated with this kind of argument:

И еще два слова о нашей точке зрения [...] Так как новое литературное движение, начатое Котляревским, возникло среди восточно-украинских говоров и отсюда двигалось на запад, то эти говоры составляют, так сказать, ядро литературной малорусской речи, что сообщает ей единство и цельность, - качества, которые имеются во всяком литературном языке и которых мы будем требовать от малорусских переводов евангелия [Žiteckij, 1905, p. 21].

Just two words about my point of view [...] As the new literary movement, started by Kotljarevs'kyj, emerged from the Eastern Ukrainian ways of speaking and from there took its way to the West, these ways of speaking make up, as a manner of saying, the kernel of the literary Little Russian speech, which conveys its unity and wholeness, - qualities, which are present in every literary language and which we will demand from the Little Russian translations of the Gospel.

The quoted passage brings together all the glory and misery in argumentations about national languages and their cultural role in historical perspective. In order to escape all stereotypes of being just a (Polish depraved) Russian dialect, it is needed for Žytec'kyj to find the beginnings of the Ukrainian language as early in history as possible. But the longer the independent development of a language is 
taken for granted the more different the outcome is expected in contrast to other languages. In the case of Ukrainian - so Žytec'kyj argues - the not so great difference to Russian is explainable by the fact that the national literary language of the Ukraine is based on its Eastern idioms and dialects.

\section{CAN LESSONS FROM HISTORY BE LEARNED?}

Using the example of the correspondence between Šachmatov and Žytec'kyj, it can be shown, that both scholars, being on top of the linguistic knowledge of their time, could agree on linguistic facts, and at the same time display fundamental contradictions concerning the political consequence of their linguistic findings. Both sides agree on the fact, that Ukrainian is a language, not just a dialect, but both sides draw different political conclusions from that fact which have an irrational point to them, which is not so much an individual deviation from logic as it is an enmeshment in the language discourses of the $19^{\text {th }}$ century.

The irrational point in Šachmatov's argument states that the Russian language could at the same time be the brother of Ukrainian and its origin, its mother, too. The concept is only understandable by taking into consideration the implication of the term "language" in the $19^{\text {th }} \mathrm{c}$ : Only those linguistic varieties can be labelled "languages" which are supported by a corresponding political unit, the "nation". As Russia has managed to become a national state (rossijskij) or an empire based on the Russian nation (russkij), the linguistic variety in use is 'historically proven' to be a language. The same chance for other linguistic varieties to historically prove that they are languages would include giving the corresponding community of speakers their political autonomy. But this consequence leads to the acknowledgement, that the supposed linguistic pair "language-nation" is just a pair of political terms. In order to salvage the supposed linguistic pair "language-nation" it is claimed that the nation as the emerging ground for both the Russian and the Ukrainian language is only the "Great Russian tribe".

The irrational point in Žytec'kyjs statements lies in the fact, that he argues as if textualization of a language would not be a political claim. As the supposed linguistic pair "language-nation" implies that a language is the written literary language used within the political unit "nation" Žytec'kyj is solicitous to demonstrate that texts of the stylistic register of the "belles lettres", written in different varieties of Ukrainian, have been constantly circulating through history and that the written variety of the Ukrainian language of his time would emerge right from the oral speech of those who therefore can be called "Ukrainians". The step from orality to literacy, of course, changes every linguistic idiom in regard to uniformity 
and gradual normalization, but can hardly serve as a base for political claims. Neither language use nor the content of the literature written in this particular language support the claim for political autonomy, without the implication - as in the discourse of the $19^{\text {th }}$ - that language use is proof of ethnic unity.

While the political attitudes of both sides cannot be consistently based on linguistics, it is hard to deny that arguments similar to those uttered at the beginning of the last century, one might happen to hear today. If we identify repeating moments in history we are able to ask ourselves if they should be avoided in the future. The Russian-Ukrainian conflict of our time would probably have taken another route, and maybe a more civilized one, if political goals had not been disguised by using language as a symbol for societal unities. On the one side, this always seems to be a good means for engaging people emotionally, but on the other side, it is of less help to negotiate over conflicting interests in order to come to satisfying solutions for both parties. Using language as a symbolic argument is counterproductive to communication.

\section{REFERENCES}

AleksandrovskiJ Ivan S., 2009, “Jazyk”'ili “narečie”? Polemika vokrug ukrainskogo jazyka v XIX v., "Vestnik Moskovskogo gosudarstvennogo oblastnogo universiteta. Serija Istorija i Političeskie Nauki", vol. 1, pp. 46-53.

ANDERson Benedict, 1991, Imagined Communities. Reflections on the Origin and Spread of Nationalism, rev. ed., Verso, London-New York.

ARistov Vadym J., 2010, Ukraïnofily: miž deržavnym i "na-cional'nym", "Naukovi Zapysky NaUKMA", vol. 104, pp. 19-23.

BASARgINA Ekaterina J., 2004, Vice-prezident Imperatorskoj Akademii nauk P.V. Nikitin: Iz istroii russkoj nauki (1867-1916 gg.), RAN, Sankt-Peterburg. Beloded Ivan K., 1968, Naučnoe nasledie P.I. Žiteckogo i sovremennost', "Voprosy Jazykoznanija", vol. 1, pp. 111-117.

BıJušKina Nadežda I., 2010, Istočniki položenija "O merach kochraneniju gosudarstvennogo porjadka i obščestvennogo spokojstva” ot 14 avgusta 1881 g., "Vestnik Nižegorodskogo universiteta. Pravo", vol. 5/1, pp. 288-293.

BoRJaK Hennadij, ed., 2013, Ukraïns 'ka identyčnist' i movne pytannja v Rosijs 'kij imperiï: sproba deržavnoho reguljuvannja (1847-1914). Zbirnyk dokumentiv i materialiv, Akademija Nauk Ukraïny, Kyïv.

CRACRAFT James, 1982, From the Russian past to the Soviet present, "Bulletin of the Atomic Scientists", vol. 32, no. 1, pp. 8-12. 
DAIBER Thomas, 1992, Die Darstellung des Zeitworts in ostslavischen Grammatiken von den Anfängen bis zum ausgehenden 18. Jahrhundert, Weiher (= Monumenta Linguae Slavicae Dialecti Veteris, Fontes et Dissertationes 32), Freiburg i. Br.

DAIBER Thomas, 2008, Romantischer Volksgeist oder Sprachidentität in gezähmter Natur, "Bulletin der Deutschen Slavistik", no. 14, pp. 75-85.

DAIBER Thomas, 2014, Slavische Grammatikschreibung, in: K. Gutschmidt, S. Kempgen, T. Berger, P. Kosta, eds., Die slavischen Sprachen. Ein internationales Handbuch zu ihrer Struktur, ihrer Geschichte und ihrer Erforschung. Band 2. 1793-1811 (= Handbücher zur Sprach- und Kommunikationswissenschaft [HSK] 32/2), de Gruyter, Berlin.

Danylenko Andrii, 2010, The Ukrainian Bible and the Valuev Circular of July 18, 1863, "Acta Slavica Iaponica", no. 28, pp. 1-21.

Danylenko Andrii, 2016, From the Bible to Shakespeare. Pantelejmon Kuliš (1819-1897) and the Formation of Literary Ukrainian, Academic Studies Press, Boston.

Del Sarto Raffaella A., 2016, Normative Empire Europe: The European Union, its Borderlands, and the 'Arab Spring', "Journal of Common Market Studies", vol. 54/2, pp. 215-232.

Domrin Alexander N., 2010, A Lost War on Terror: Forgotten Lessons of the Russian Empire, "Michigan State Journal of International Law", vol. 19/1, pp. 63-94.

Esipova Valerija A., 2014, K voprosu ob istorii perevoda teksta Novogo Zaveta F.S. Moračevskogo: po materialam ORKP NB TGU, "Vestnik Tomskogo Gosudarstvennogo Universiteta. Filologija", no. 384, pp. 87-94.

Frank Stephen P., 1999, Crime, Cultural Conflict, and Justice in Rural Russia, 1856-1914, University of California, Los Angeles (= Studies on the History of Society and Culture 31).

Glassl Horst, 1985, Die Kyrillo-Methodianische Bruderschaft als Erscheinung der ukrainischen Romantik, in: J. Bojko-Blochin, ed., Ukrainische Romantik und Neuromantik vor dem Hintergrund der europäischen Literatur, Winter, Heidelberg, pp. 97-104.

HLUŠČENKO Vladimir A., 2014, Russkie jazykovedy v bor 'be za ravnopravie russkogo i ukrainskogo literaturnych jazykov (konec XIX v. - načalo XX v.), in: L.A. Kudrjavcev, ed., Russkij jazyk i literatura. Problemy izučenija i prepodavanija. Sbornik naučnych trudov, vyp. 8, Ukrainskaja Associacija prepodavatelej russkogo jazyka i literatury, Kiev, pp. 18-25. 
Horbatsch Olexa, 1964, Die vier Ausgaben der kirchenslavischen Grammatik von M. Smotryćky, Harrassowitz, Wiesbaden (= Frankfurter Abhandlungen zur Slavistik 7).

JAGIĆ Vatroslav, 1895, Razsuždenija južnoslavjanskoj i russkoj stariny o cerkovno-slavjanskom jazyke, Imperatorskaja Akademija Nauk, Sankt Peterburg.

Kamusella Tomasz, 2012, The Change of the Name of the Russian Language in Russian from Rossiiskii to Russkii: Did Politics Have Anything to Do with It?, "Acta Slavica Iaponica", no. 32, pp. 73-96.

Kotenko Tat'jana I., 2014, Avtografy perevoda teksta Novogo Zaveta F.S. Moračevskogo v fondach biblioteki Rossijskoj Akademii Nauk: Novye dannye, "Vestnik Tomskogo gosudarstvennogo universiteta. Filologija", no. 384, pp. 102-106.

KRETSCHMER Anna, 1994, Und noch einmal zur Diglossie, in: T. Berger, ed., Linguistische Beiträge zur Slawistik aus Deutschland und Österreich, Gesellschaft zur Förderung Slawistischer Studien, Wien, pp. 181-194.

Makarov Vladimir I., 2012, Perepiska A.A. Šachmatova i P.I. Žiteckogo, "Učennye zapiski Kurskogo gosudarstvennogo universiteta", vol. 3(23)/2.

Makarov Vladimir I., 2015, Prednaznačenie čeloveka - "uveličit'summu dobra na zemle" (A.A. Šachmatov), in: O.N. Krylova, M.N. Priemyševa, eds., Akademik A.A. Šachmatov. Žizn', tvočestvo, naučnoe nasledie, Nestor-Istorija, Sankt Peterburg, pp. 8-23.

Michutina Irina V., 2003, Ukrainskij vopros v Rossii (konec XIX - načalo $X X$ veka), Logos, Moskva.

Moser Michael, 2005, Das Ukrainische als Kirchensprache, Lit, Berlin.

Ob otmene stesnenij malorusskogo pečatnogo slova (na pravach rukopisi), 1905, Imperatorskaja Akademija Nauk, Sankt Peterburg.

Pavlovskij Aleksej P., 1978, Grammatika malorossijskago narečija [SPb 1818], Pribavlenie k Grammatike malorossijskogo narečija [SPb 1822], ed. O. Horbatsch, Ukrainische Universität, München.

Remy Johannes, 2007, The Valuev Circular and Censorship of Ukrainian Publications in the Russian Empire (1863-1876): Intention and Practice, "Canadian Slavonic Papers", vol. 49, no. 1/2, pp. 87-120.

Remy Johannes, 2016, Brothers or Enemies. The Ukrainian National Movement and Russia, from the 1840s to the 1870s, University Press, Toronto.

Samarin Jurij F., 1877, Iz dnevnika, vedennogo Ju. F. Samarinym v Kieve, v 1850 godu, "Russkij Archiv", no. 6, vol. 2, pp. 229-232.

Schelling Friedrich Wilhelm Joseph, 1985, Ausgewählte Schriften, in: M. Frank, ed., 6 vols., Suhrkamp, Frankfurt am Main. 
Senkus Roman, 1993, Zhytetsky, Pavlo, [printed 1993, republished] in: Internet Encyclopedia of Ukraine, ed. Canadian Institute of Ukrainian Studies, University of Alberta, University of Toronto, http://www.encyclopediaofukraine. com (accessed: 11.12.2018).

Simonova Inna A., 1988, O vzaimosvjazi slavjanofil'stva s ideologiej KirilloMefodievskogo obščestva. F.V. Čižkov i Kirillo-Mefodievcy, "Sovetskoe Slavanovedenie", no. 1, pp. 42-54.

SinICA Irina A., 2014, Pavel Ignatovič Žiteckij i razvitie gumanitarnoj mysli XIX veka, "Mova", no. 21, pp. 15-18.

SolchanyK Roman, 1985, Language Politics in the Ukraine, in: I.T. Kreindler, ed., Sociolinguistic Perspectives on Soviet National Languages. Their Past, Present and Future, Mouton, Berlin-New York-Amsterdam, pp. 57-105 (= Contributions to the Sociology of Language 40).

Symaniec Virginie, 2013, La construction idélologique slave orientale: Langues, races et nations dans la Russie du XIXe siècle, "Revue des Etudes Slaves", vol. 84, no. 1/2, pp. 223-233.

TRUBAČEv Oleg N., 2005, Russkij - rossijskij. Istorija, dinamika, ideologija dvuch atributov nacii, in: G.A. Bogatova, I.B. Es'kova, I.G. Panova, eds., Vpoiskach edinstva. Vzgljad filologa na problemu istokov Rusi, 3 Aufl, RAN, Moskva, pp. 225-236.

Vulpius Ricarda, 2005, Jazykovaja politika v Rossijskoj imperii i Ukrainskij perevod Biblii (1860-1906), “Ab Imperio”, no. 2, pp. 191-224.

ŽrteCKIJ Pavel I., 1878, Tekst Evangelija Luki iz peresopnicy rukopisi, in: V.I. Modestov, ed., Trudy III Archeologičeskogo S"ezda v Kieve 1874 g., vol. 2, Akad., Kiev, pp. 43-111.

ŽrteCKIJ Pavel I., 1905, O perevodach evangelija na malo-russkij jazyk, "Izvestija otdelenija russkago jazyka i slovesnosti Imperatorskoj Akademii nauk", vol. 10/4, pp. 1-65.

Thomas Daiber

PAWŁO ŻYTEC'KYJ I ALEKSIEJ SZACHMATOW W SPRAWIE

Streszczenie

W artykule omówiono niektóre listy A.A. Szachmatowa i P.I. Żyteckiego z początku XX wieku, w których autorzy zajmują się zagadnieniem ukraińskich przekładów Biblii. Argumenty językowe w korespondencji zanalizowano na tle dziewiętnastowiecznych poglądów na temat ,języka 
narodowego". Wysnuto wniosek, że obaj lingwiści, chociaż różnią się w poglądach na temat tego, czy Ukraina powinna otrzymać polityczną niezależność, podnoszą swoje argumenty w ramach wspólnego dyskursu.

\section{PAVLO ŽYTEC'KYJ AND ALEKSEJ A. ŠACHMATOV ON LANGUAGE IDEOLOGY AND THE STATUS OF THE UKRAINIAN LANGUAGE}

\section{Summary}

The article is concerned with some letters from P.I. Zhiteckij and A.A. Shachmatov from the beginning of the $20^{\text {th }} \mathrm{c}$. related to Ukrainian Bible translations. The language arguments of the correspondence are analyzed within the framework of linguistic views of the $19^{\text {th }}$ century on the issue of a 'national language'. It is seen, that both linguists are arguing within a common discourse, although proposing different answers to the question, whether the Ukraine should receive political independence. 